\title{
Evaluation of Culture Media for Growth Characteristics of Fungal Leaf Blight Complex of Tomato
}

\author{
S. Pavan Kumar ${ }^{1 *}$, M.K. Mishra ${ }^{2}$ and K.C. Sahu ${ }^{2}$ \\ ${ }^{1}$ College of Agriculture, Orissa University of Agriculture and technology, \\ Bhubaneswar-751003, India \\ ${ }^{2}$ Department of Plant Pathology, OUAT, Bhubaneswar-751003, India \\ *Corresponding author
}

\begin{tabular}{|l|}
\hline Ke y w o r d s \\
$\begin{array}{l}\text { Alternaria solani, } \\
\text { Fusarium oxysporum and } \\
\text { Curvularia lunata }\end{array}$ \\
\hline Article Info \\
\hline $\begin{array}{l}\text { Accepted: } \\
10 \text { October } 2018 \\
\text { Available Online: } \\
10 \text { November } 2018\end{array}$ \\
\hline
\end{tabular}

A B S T R A C T

Tomato crop exhibited symptoms occurring on the oldest leaves as small, brownish to black lesions which are due to foliar blight disease and it was caused by a complex of mycoflora viz, Alternaria solani, Fusarium oxysporum and Curvularia lunata. The disease complex causes considerable yield as well as post-harvest losses. A. solani produced blackish, fluffy mycelium with septate, beaked conidia on PDA. Fusarium oxysporum exhibited dull to fluffy white mycelium with slight faint reddish tinge at the middle. Curvularia lunata had septate mycelium which was black in the periphery and brownish black in the middle with tri-septate conidia. The growth of three fungal pathogens were tested under eight different solid media and compared with each other. Maximum radial growth of A. solani $(63.00 \mathrm{~mm}), F$. oxysporum $(60.50 \mathrm{~mm})$ and $C$. lunata $(58.10 \mathrm{~mm})$ was supported by PDA. Oat meal agar supported better growth $(42.33 \mathrm{~mm})$ next to PDA for $A$. solani, Brown's agar supported better growth next to PDA for $F$. oxysporum $(27.17 \mathrm{~mm})$ \& C. lunata $(54.73 \mathrm{~mm})$. Sabouraud's agar, Malt extract agar and Richard's agar showing least radial growth for Alternaria solani $(10.60 \mathrm{~mm})$, Fusarium oxysporum $(9.77 \mathrm{~mm})$ and Curvularia lunat $(12.83 \mathrm{~mm})$ respectively. The study will be helpful for further investigation on the physiology of the fungus and management of disease. The investigation may be useful for taxonomic study of the fungus.

\section{Introduction}

Tomato is considered as the world's largest vegetable crop after potato and sweet potato but it tops the list of canned vegetables. It is one of the most important "protective foods" because of its special nutritive value. It is an important condiment in most diets and a very cheap source of vitamins. It also contains a large quantity of water (\%), calcium (\%) and Niacin all of which are of great importance in the metabolic activities of man. Tomato is a good source of vitamins $\mathrm{A}, \mathrm{C}$ and $\mathrm{E}$ and minerals that are very good for body and protect the body against diseases (Taylor, 1987). Like other crops this crop is also subjected to several diseases caused by fungi, bacteria, viruses, nematodes and abiotic factors (Balanchard, 1992). The crop suffers from a number of foliar diseases such as early blight, also called Alternaria leaf blight (Alternaria solani), late blight (Phytophthora 
infestans), Septoria leaf spot (Septoria lycopersici), Gray mold (Botrytis cinerea) and leaf mold (Fulvia fulva). Among the fungal diseases, early blight also known as target spot disease incited by Alternaria solani (Henning and Alexander 1950, Raut et al., 2008) Jones and Grout, Fusarium blight incited by Fusarium oxysporum f. sp. lycopersici. Present study helpful for further investigation on the physiology of the fungus and management of fungal blight of tomato.

\section{Materials and Methods}

\section{Media preparation}

All the ingredients (Table 1) were dissolved in $500 \mathrm{ml}$ of distilled water and agar agar was added in $500 \mathrm{ml}$ distilled water in another flask. The two solutions were mixed and volume made up to $1000 \mathrm{ml}$. the media then was autoclaved at 15 psi. or $1.1 \mathrm{~kg} / \mathrm{cm}^{2}$ for 15 minutes in autoclave. After sterilization $250 \mathrm{mg}$ streptomycin sulphate was added to one liter sterilized media to avoid bacterial contamination. Twenty $\mathrm{ml}$ of each media was poured into sterilized petri dish and solidified under laminar airflow.

\section{Incorporation of the fungus culture}

The pure culture of the fungus was obtained by culturing the fungus on potato dextrose agar medium and making the fresh culture from "hyphal tip" selected from the periphery of actively growing colony under aseptic conditions. Pure culture was maintained by routine subculturing after 14 days.

The mycelial blocks were cut out of 10 days old fungal colony near the margin by means of sterilized cork borer of $5 \mathrm{~mm}$ diameter. These blocks were transferred to the center of the petri plates by means of a sterilized inoculating needle. All these were done under perfect aseptic condition inside an inoculation chamber which was sterilized previously by spraying formaldehyde solution (4\%) and ultra violet (U. V.) radiation.

\section{Fungus growth measurement technique}

In case of all solid media, linear growth of the fungus was determined directly by measuring the diameter of the colonies in the same axis after 7 days of inoculation. Linear growth of the colony was measured with the help of fine transparent plastic scale in millimeter.

\section{Statistical analysis}

The experiments were done under controlled laboratory conditions, and the data were analyzed following completely randomized design (CRD).

\section{Results and Discussion}

Growth of Alternaria solani in different media

A Total of eight growth media were tested including potato dextrose agar for the growth of Alternaria solani. Radial growth ( $\mathrm{mm}$ ) of Alternaria solani were measured and analyzed and presented in (Table 2). There were significant differences among the all the growth media for the growth of Alternaria solani compared to potato dextrose agar. The fungus grew luxuriantly in PDA but in other media the growth of fungus significantly was lowered Oat meal agar supported better growth $(42.33 \mathrm{~mm})$ next to PDA $(63.0 \mathrm{~mm})$.

Potato dextrose rose Bengal (13.00mm), Malt extract agar $(10.70 \mathrm{~mm})$ and Sabouraud's agar exhibited statistically similar growth pattern. Richard's agar and Brown's agar $(10.60 \mathrm{~mm})$ also exhibited similar growth pattern eight days after inoculation. This was supported by the studies conducted by Kaul and saxena (1988), Varma (2007). 
Table.1 Composition and preparation of different media (Dhingra and Sinclair, 1995)

\begin{tabular}{|c|c|c|c|}
\hline \multicolumn{2}{|l|}{ 1. potato dextrose agar } & \multicolumn{2}{|l|}{ 7. Sabouraud's dextrose Agar } \\
\hline Peeled potato chips & $200 \mathrm{~g}$ & Dextrose & $40 \mathrm{~g}$ \\
\hline Dextrose & $20 \mathrm{~g}$ & Peptone & $10 \mathrm{~g}$ \\
\hline Agar agar & $20 \mathrm{~g}$ & Agar agar & $15 \mathrm{~g}$ \\
\hline Distilled water & $1000 \mathrm{ml}$ & Distilled water & $1000 \mathrm{ml}$ \\
\hline \multicolumn{2}{|l|}{ 2. Oat meal agar } & \multicolumn{2}{|l|}{ 8. Brown's agar } \\
\hline Oat flakes & $40 \mathrm{~g}$ & Glucose & $2 g$ \\
\hline Agar agar & $20 \mathrm{~g}$ & $\begin{array}{l}\text { Dipotassium } \\
\text { phosphate }\end{array}$ & $1.25 \mathrm{~g}$ \\
\hline Distilled water & $1000 \mathrm{ml}$ & Asparagines & \\
\hline \multicolumn{2}{|l|}{ 3. Malt extract agar } & Magnesium sulphate & $0.75 \mathrm{~g}$ \\
\hline Malt extract & $20 \mathrm{~g}$ & Agar agar & $20 \mathrm{~g}$ \\
\hline Agar agar & $20 \mathrm{~g}$ & Distilled water & $1000 \mathrm{ml}$ \\
\hline Distilled water & $1000 \mathrm{ml}$ & & \\
\hline \multicolumn{4}{|c|}{$\begin{array}{l}\text { 4. Potato dextrose rose Bengal } \\
\text { agar }\end{array}$} \\
\hline $\begin{array}{l}\text { Potato infusion from } \\
\text { sliced potato }\end{array}$ & $200 \mathrm{~g}$ & & \\
\hline Dextrose & $20 \mathrm{~g}$ & & \\
\hline Rose bengal & $0.0084 \mathrm{~g}$ & & \\
\hline Agar agar & $15 \mathrm{~g}$ & & \\
\hline Distilled water & $1000 \mathrm{ml}$ & & \\
\hline \multicolumn{4}{|l|}{ 5. Richard's Agar } \\
\hline Sucrose & $50 \mathrm{~g}$ & & \\
\hline Potassium nitrate & $10 \mathrm{~g}$ & & \\
\hline $\begin{array}{l}\text { Monopotassium } \\
\text { dihydrogen phosphate }\end{array}$ & $5 \mathrm{~g}$ & & \\
\hline Magnesium sulphate & $2.5 \mathrm{~g}$ & & \\
\hline Ferric chloride & $0.02 \mathrm{~g}$ & & \\
\hline Agar-agar & $15 \mathrm{~g}$ & & \\
\hline Distilled water & $1000 \mathrm{ml}$ & & \\
\hline \multicolumn{2}{|l|}{ 6. Czapek's Dox Agar } & & \\
\hline Sucrose & $30 \mathrm{~g}$ & & \\
\hline Sodium nitrate & $2 \mathrm{~g}$ & & \\
\hline Potassium chloride & $0.5 \mathrm{~g}$ & & \\
\hline $\begin{array}{l}\text { Potassium dihydrogen } \\
\text { phosphate }\end{array}$ & $1 \mathrm{~g}$ & & \\
\hline Magnesium sulphate & $0.5 \mathrm{~g}$ & & \\
\hline Ferric chloride & $0.01 \mathrm{~g}$ & & \\
\hline Agar-agar & $20 \mathrm{~g}$ & & \\
\hline Distilled water & $1000 \mathrm{ml}$ & & \\
\hline
\end{tabular}


Table.2 Growth of three foliar fungal pathogens in various growth media

\begin{tabular}{|c|c|c|c|c|}
\hline \multirow[t]{2}{*}{ Sr. No. } & \multirow[t]{2}{*}{ Treatments } & \multicolumn{3}{|c|}{ Radial growth of pathogen ( $\mathrm{mm}$ ) } \\
\hline & & Alternaria solani & Fusarium oxysporum & Curvularia lunata \\
\hline 1 & $\mathrm{~T}_{1}$ & $42.33(6.75)$ & $21.33(4.67)$ & $34.67(5.93)$ \\
\hline 2 & $\mathrm{~T}_{2}$ & $13.00(3.81)$ & $13.60(3.75)$ & $40.90(6.43)$ \\
\hline 3 & $\mathrm{~T}_{3}$ & $10.70(3.08)$ & $9.77(3.19)$ & $50.43(7.14)$ \\
\hline 4 & $\mathrm{~T}_{4}$ & $31.33(5.79)$ & $10.83(3.36)$ & $12.83(3.65)$ \\
\hline 5 & $\mathrm{~T}_{5}$ & $27.73(5.05)$ & $22.83(4.83)$ & $17.73(4.27)$ \\
\hline 6 & $\mathrm{~T}_{6}$ & $10.60(3.54)$ & $12.33(3.57)$ & $73.27(8.59)$ \\
\hline 7 & $\mathrm{~T}_{7}$ & $29.00(5.61)$ & $27.17(5.26)$ & $54.73(7.43)$ \\
\hline \multirow[t]{3}{*}{8} & T8 (Control) & $63.00(8.09)$ & $60.50(7.81)$ & $58.10(7.65)$ \\
\hline & $\operatorname{SEm}( \pm)$ & 1.2 & 1.07 & 1.5 \\
\hline & CD (5\%) & 3.6 & 3.2 & 4.5 \\
\hline
\end{tabular}

*Figures in the parentheses indicate $\sqrt{(x+0.5)}$ transformed values

$\mathrm{T}_{1-}$ Oat meal agar, $\mathrm{T}_{2-}$ Potato dextrose rose Bengal agar, $\mathrm{T}_{3-}$ Malt extract agar, $\mathrm{T}_{4-}$ Richard's agar, $\mathrm{T}_{5-}$ Czapek's dox agar, $\mathrm{T}_{6-}$ Sabouraud's agar, $\mathrm{T}_{7}$. Brown's agar, $\mathrm{T}_{8}$-Potato dextrose agar.

Growth of Fusarium oxysporum in different media

Significant different growth habit were also observed in Fusarium oxysporum with highest radial growth in PDA $(60.50 \mathrm{~mm})$, malt extract lower growth $(9.77 \mathrm{~mm})$ followed by Richard's agar $(10.83 \mathrm{~mm})$ and they were at par with potato dextrose rose Bengal agar $(13.60 \mathrm{~mm})$ and Sabouraud's agar $(12.33 \mathrm{~mm})$. Oat meal agar $(21.33 \mathrm{~mm})$ and Czapek's dox agar $(22.83 \mathrm{~mm})$ exhibited similar pattern of growth of Fusarium oxysporum. The finding coincided with Kulakarni (2006).

\section{Growth of Curvularia lunata in different media}

Curvularia lunata also behaved significantly different in growth habits in all eight media. Sabouraud's agar was recorded highest growth of the Curvularia lunata $(73.27 \mathrm{~mm})$ which was more than growth in PDA (58.10mm). No significance difference observed among PDA $(58.10 \mathrm{~mm})$, brown's agar $(54.73 \mathrm{~mm})$ for the growth of Curvularia lunata. Richard's agar supported lowest growth (12.83mm). Curvularia lunata exhibited similar growth pattern in Malt extract agar $(50.43 \mathrm{~mm})$ and Browns agar (54.73mm).

Potato dextrose agar showed best growth againstthree test pathogens. Oat meal agar supported better growth $(42.33 \mathrm{~mm})$ next to PDA for Alternaria solani, Brown's agar for Fusarium oxysporum and Curvularia lunat. Sabouraud' sagar, Malt extract agar and Richard's agar showing least radial growth for Alternaria solani, Fusarium oxysporum and Curvularia lunat respectively.

\section{References}

Balanchard, D. 1992. A color atlas of tomato diseases. Wolfe Pub. Ltd., Brook house, London, P. 298.

Datar, V.V, Mayee, C.D. 1981. Assessment of losses in tomato yield due to the early blight. Indian Phytopath 34: 191-195.

Dhingra, Sinclair, J.B. 1995. 2nd Edition, Basic plant Pathology Methods, Lewis 
Publishers, Boca Raton, London, Tokyo (1995).

Henning, R. G, Alexander, L.J. 1950. Evidence of existence of physiologic races of Alternaria solani. Pl.Dis. Rept., 43: 298-308.

Kaul, A.K, Saxena, H.K. 1988. Physiologic specialization in Alternaria solani causing early blight of potato. Indian J.Mycol. Pl. Patho. 18 (2): 128-132.

Kulkarni, Sumitra, P. 2006. Studies on Fusarium oxysporum Schlecht Fr, f. sp. gladioli (Massey) Synd \& Hans. Causing wilt of gladiolus. MSc. (Agri) Thesis. University of Agriculture Sciences, Dharwad (India).pp.42-76.

Raut, B. T., Sali, V. M., Giri, G.K. 2008. Host differential reaction of Alternaria solani causing blight in tomato (Abs) paper presented in national Symposium and 16th annual meet of IPS (New Delhi) "Plant disease scenario in organic Agriculture for ecofriendly sustainability" Jan-10-12, 2008RWRRS, Mahabaleshwar, PP: 19.

Taylor, J. H. 1987. Text of lectures delivered at the national workshop on fruit and vegetable seedlings production held at NIHORT 9-13.

Varma, K. P, Sing S, Gandhi, S. K 2007. Variability among of Alternaria solani isolates causing early blight of tomato. Indian Phytopath. 60 (2): 180-186.

\section{How to cite this article:}

Pavan Kumar, S., M.K. Mishra and Sahu, K.C. 2018. Evaluation of Culture Media for Growth Characteristics of Fungal Leaf Blight Complex of Tomato. Int.J.Curr.Microbiol.App.Sci. 7(11): 1073-1077. doi: https://doi.org/10.20546/ijcmas.2018.711.124 